\title{
PENERIMAAN MAHASISWA BARU BERBASIS WEBSITE PADA UNIVERSITAS KARYADARMA KUPANG
}

\author{
Dina Maria, Hildayanti Henuk
}

\author{
Program Studi Teknik Informatika Universitas Karyadarma Kupang \\ E-mail :dinamaria99dagama@gmail.com,hyldhayanti93@gmail.com
}

\begin{abstract}
New Student Admission Information System at Karyadarma University has not used a web-based information system. This information system is an information system used to facilitate the registration administration process so as to make it easier for the Admissions Committee at the University of Kupang Karyadarma. In developing the New Student Admission Information System using the Laravel framework method. This information system uses the PHP programming language and MYSQL database server. The system testing method uses blackbox and usability testing. The results of this study are a website-based New Student Admission Information System that can help the ongoing performance. The results of testing the software that was developed obtained a functionality value of 1 (Good), testing the usability aspect obtained results with a percentage of $94.66 \%$ (Very Eligible).
\end{abstract}

Keywords: Information Systems, New Student Admissions, Website Laravel framework

\section{PENDAHULUAN}

Pada umumnya Universitas memiliki beberapa sistem informasi untuk mengontrol manajemen kegiatan di kampus, tetapi tidak semua memiliki sistem informasi penerimaan mahasiswa baru. Teknologi informasi adalah suatu teknologi yang digunakan untuk mengolah data, termasuk memproses, mendapatkan, menyusun, menyimpan, memanipulasi data berbagai cara untuk menghasilkan informasi yang berkualitas yaitu informasi yang relevan, akurat, dan tepat waktu yang digunakan untuk keperluan pribadi, bisnis, dan pemerintahan yang merupakan aspek strategi untuk pengambilan keputusan [1]. Universitas Karyadarma Kupang memiliki 10 (sepuluh) Program studi antara lain : (1) PG-PAUD S1, (2) PG-SD S1, (3) Pend. Jasmani Kesehatan dan Rekreasi S1, (4) Pend. Bahasa dan Sastra Indonesia S1, (5) Ilmu Hukum S1, (6) Ilmu Pemerintahan S1, (7) Teknik Informatika S1, (8) Perencanaan Wilayah dan Kota S1, (9) Agrobisnis S1, (10) Agroteknologi S1. Hasil wawancara dengan Kepala Tata Usaha Universitas Karyadarma Kupang mengenai proses pendaftaran mahasiswa baru sebagai berikut : (1) Calon mahasiswa mengisi formulir yang telah disediakan, (2) Calon Mahasiswa melengkapi persyaratan pendaftaran, (3) Bagian administrasi Tatausaha Kampus adalah pihak yang melakukan proses pendaftaran mahasiswa baru, (4) Formulir diterima oleh Petugas
Pendaftaran Calon Mahasiswa, (5) Hasilnya akan diumumkan melalui telepon/papan pengumuman yang ada dikampus, (6) Mahasiswa Baru yang diterima melakukan Her registrasi sebagai Mahasiswa Baru (7) Universitas Karyadarma Kupang belum memiliki Sistem Informasi Penerimaan Mahasiswa Baru sehingga mengurangi batasan informasi bagi calon mahasiswa. Untuk mengatasi masalah tersebut penulis memberikan solusi dengan membangun sebuah Sistem Informasi Penerimaan Mahasiswa Baru berbasis Website (SIMBUK) sehingga mempermudah akses informasi pendaftaran bagi calon Mahasiswa Baru dan pengolahan datanya terintegrasi serta terkelola dengan baik. Untuk melihat alur sistem menggunakan Class Diagram. Dalam pembuatan sistem digunakan alat bantu pengembangan sistem yaitu PHP dan database MYSQL.

\section{METODE PENELITIAN}

Metode penelitian yang digunakan adalah penelitian dan pengembangan (Research and Development), adalah Metode penelitian yang digunakan untuk menghasilkan produk tertentu, dan menguji keefekifan produk tersebut. Perancangan Sistem Informasi Penerimaan Mahasiswa Baru berbasis Website yaitu Research and Development R\&D, dengan model waterfall. Model air terjun (waterfall) adalah suatu proses pembuatan sistem informasi secara 
terstruktur dan berurutan dimulai dari studi kelayakan, investigsi, analisis, perancangan, penerapan, perawatan [2]

\section{Studi Kelayakan}

Dilakukan untuk melihat apakah pengembangan sistem yang lama perlu dilakukan.

\section{Tahapan Investigasi}

Tahapan ini dilakukan untuk menentukan apakah terjadi suatu masalah atau adakah peluang suatu sistem informasi dikembangkan dan menelusuri sistem seperti apa yang dibutuhkan. Pada tahapan studi kelayakan ini juga perlu dilakukan untuk menentukan apakah sistem informasi yang akan dikembangkan merupakan solusi yang layak. Pada tahapan ini peneliti melakukan pengumpulan data dengan cara Observasi, Wawancara, dan Dokumentasi. Menurut Sugiyono, teknik pengumpulan data merupakan langkah yang paling strategis dalam penelitian, karena tujuan utama dari penelitian adalah mendapatkan data [4]

\section{Tahap Analisis}

Tahap analisis bertujuan untuk mencari kebutuhan pengguna dan organisasi serta menganalisis bagaimana sistem akan dibuat.

\section{Perancangan Model Sistem}

Sistem dibuat dengan melakukan perancangan mode untuk mendapatkan model klasifikasi. Adapun alur proses perancangan model sistem dilihat pada gambar 1 berikut:

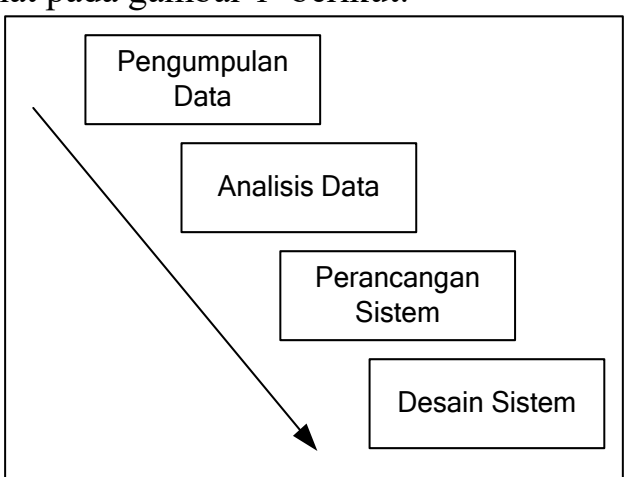

Gambar 1. Diagram blok perancangan model sistem

dimulai dengan pengumpulan data yang berkaitan dengan sistem informasi yang akan dibangun [3]. Analisa data yang dikumpulkan dari tahapan pengumpulan data dan proses perancangan sistem berupa mendesain tampilan sistem antarmuka berupa prototype dari sistem informasi yang akan dibangun. Proses perancangan meliputi perancang penggunaan model UML (Unfield Modelling Language) antaralain: Use case, Class Diagram, konseptual database dan rancangan antarmuka sistem informasi penerimaan mahasiswa baru pada Universitas Karayadarma Kupang. Pada tahap akhir penulis membangun sistem informasi penerimaan mahasiswa baru pada Universitas Karayadarma Kupang mengunakan framework Laravel dengan menggunakan Database Manajemen System MYSQL.

1. Use case

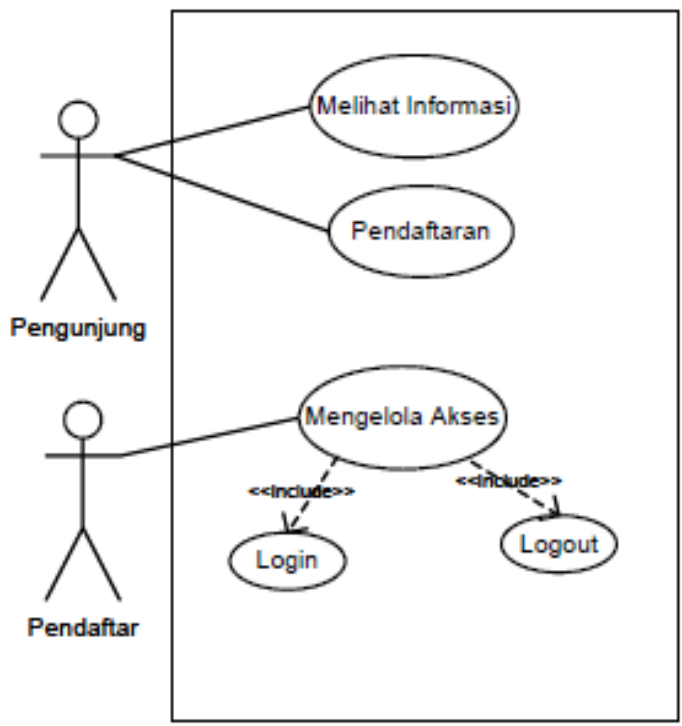

Gambar 2. Use Case Diagram pengunjung dan pendaftar sistem baru

2. Class diagram:

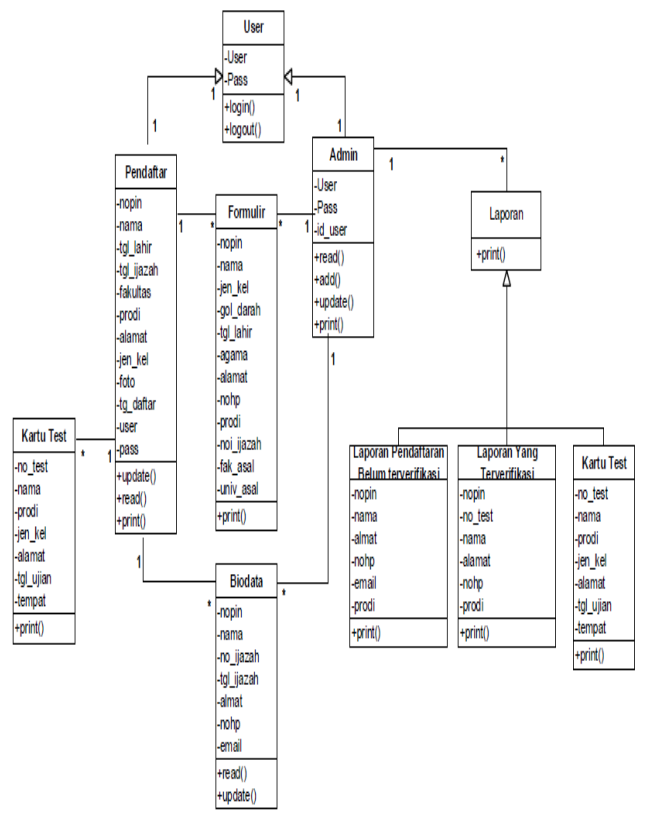

Gambar 3. Class Diagram Admin dan Pendaftar Sistem Baru 
3. Antarmuka Sistem Informasi

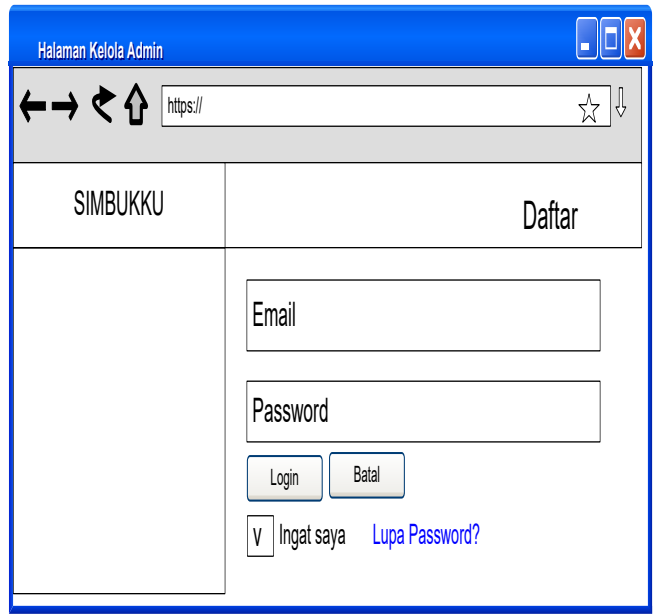

Gambar 4. Halaman Login

\section{HASIL DAN PEMBAHASAN Halaman Beranda}

Beranda berfungsi untuk menampilkan halaman utama saat pengunjung masuk dalam aplikasi/website, menu berita untuk menampilkan berita yang yang diposting, menu Login yang berfungsi untuk menamilkan halaman login untuk admin dan mahasiswa dan menu Register untuk pengunjung dapat daftar menjadi mahasiswa baru. Pada halaman beranda ini juga menampilkan profil tentang website, berita dan dan slide foto dari foto berita.

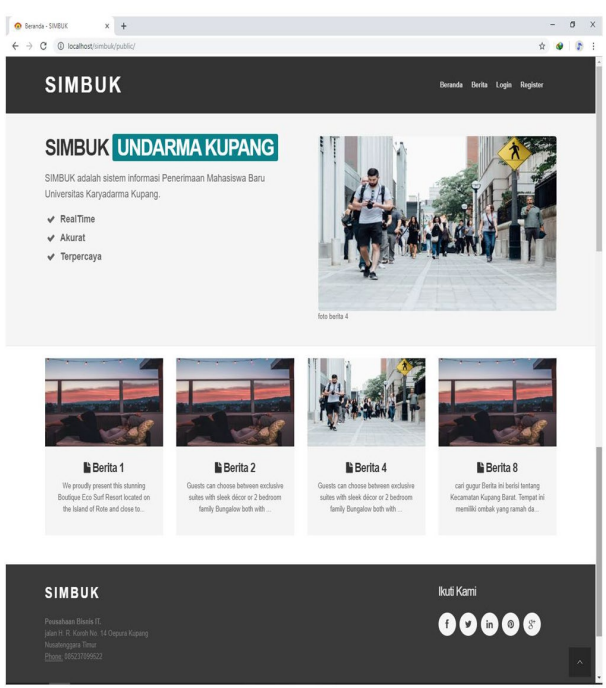

Gambar 5. Halaman Beranda

\section{- Menu Admin}

Berfungsi untuk menampilkan data admin, menambah data, mengubah data dan menghapus data admin.

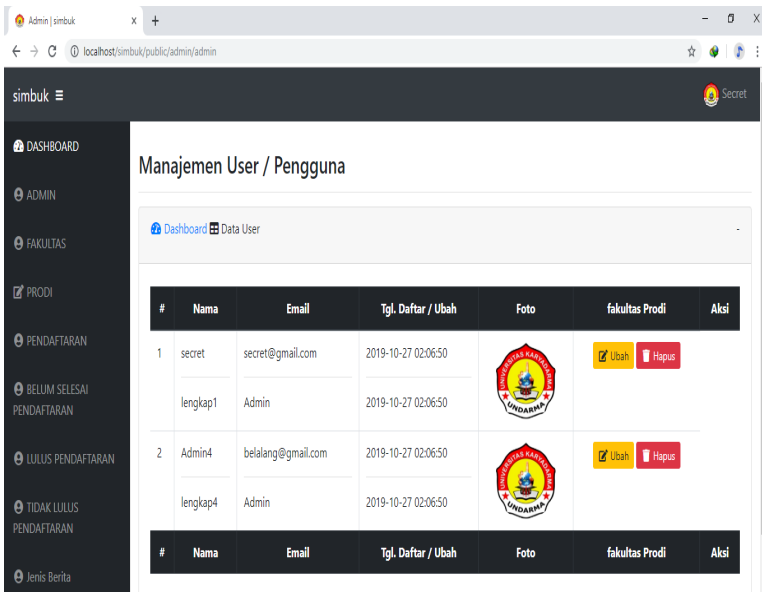

Gambar 6. Menu admin

\section{- Menu Fakultas}

berfungsi untuk menampilkan data fakultas, menambah data, mengubah data dan menghapus data fakultas.

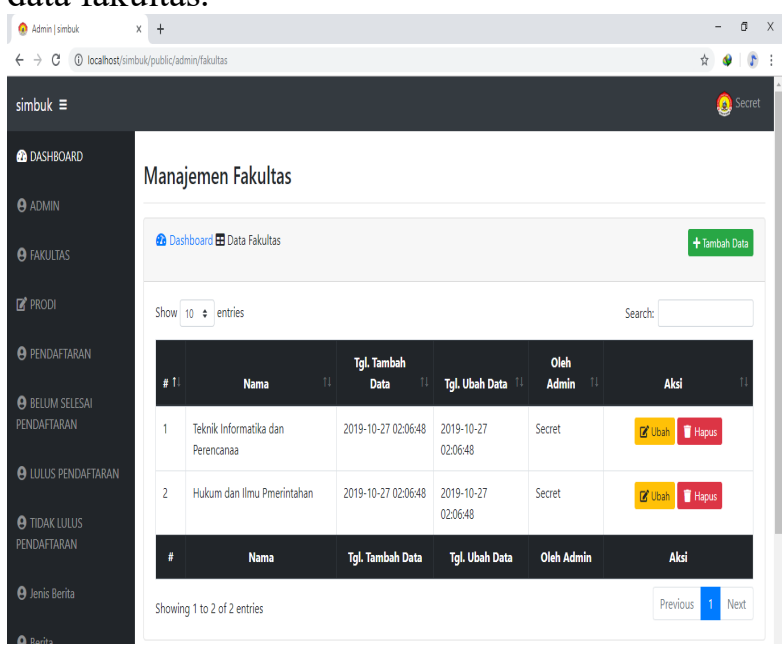

Gambar 7. Menu fakultas

\section{- $\quad$ Menu Prodi}

Pada menu prodi berfungsi untuk menampilkan data program studi, menambah data, mengubah data dan menghapus data prodi.

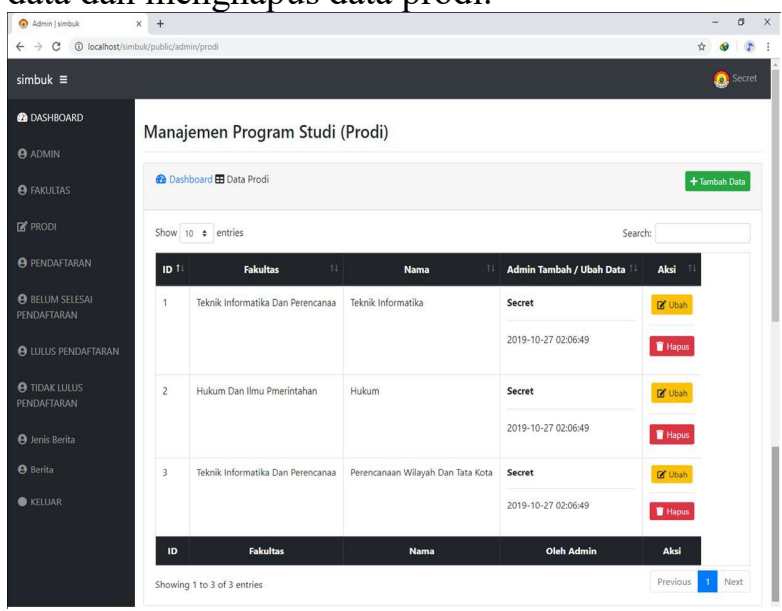

Gambar 8. Menu prodi

\section{- Menu Pendaftaran}

Pada menu pendaftaran berfungsi untuk menampilkan semua data calon pendaftar yang telah mendaftar, baik yang lulus, belum lulus, 
maupun tidak lulus pendaftaran. Pada halaman ini juga admin dapat merubah data pendaftar, menghapus, selain itu admin dapat memferfikasi pendaftar menjadi lulus atau tidak lulus atau pun menjadi belum selesai mendaftar.

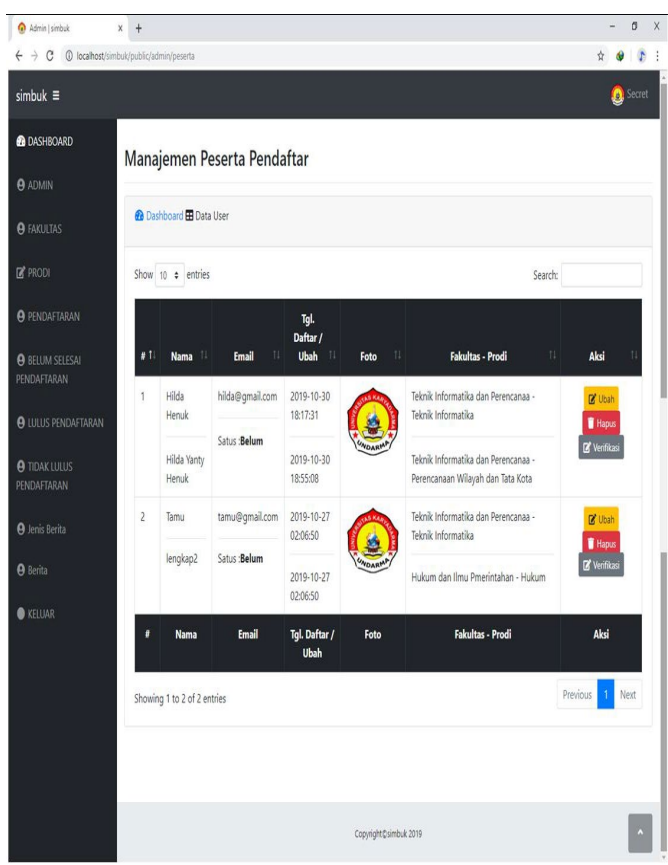

Gambar 9. Menu Pendaftaran

\section{Testing}

\section{Validasi Ahli Media}

Pengujian dan Analisis Aspek Functionalty Sebelum produk diuji kelapangan atau lokasi penelitian, terlebih dahulu produk diuji oleh 3 ahli media dengan rumus perhitungan nilai validasi sebagai berikut:

$x=1-\frac{A}{B}$

Keterangan :

$\mathrm{X}=$ Functionalty

$\mathrm{A}=$ Jumlah total fungsi yang tidak valid

$\mathrm{B}=$ Jumlah seluruh fungsi

$x=1-\frac{0}{75}$

$x=1$

Berdasarkan rumus pengukuran implementasi functionalty tersebut, functionalty dikatakan baik jika nilai X lebih dari 0,5 mendekati 1 . Berdasarkan hasil tersebut maka pengujian sistem aspek functionalty dinyatakan layak

\section{Pengujian dan Analisis Aspek Usability}

Table 1. Perhitungan Skor Total Pengujian Usability Jumlah Skor Hasil

\begin{tabular}{|c|c|c|c|}
\hline & Jumlah & Skor & Hasil \\
\hline SS & 218 & 4 & 1090 \\
\hline S & 330 & 4 & 1320 \\
\hline RG & 96 & 3 & 288 \\
\hline TS & 0 & 2 & 0 \\
\hline STS & 0 & 1 & 0 \\
\hline \multicolumn{4}{|r}{} \\
\hline
\end{tabular}

Skor total yang telah didapat kemudian dihitung untuk menentukan kualitas. Berikut penyelesaian akhir untuk pengujian usability.

$$
\begin{aligned}
& \text { index }(\%)=\frac{\text { Jumlah Skor Total }}{\text { Nilai Tertingggi }} \times 100 \\
& =\frac{2698}{30 \times 5 \times 19} \times 100 \\
& =\frac{2698}{2850} \times 100 \\
& =94,66 \%
\end{aligned}
$$

Table 2. Kategori Penilaian Faktor Kualitas

\begin{tabular}{|l|l|}
\multicolumn{2}{|c}{ Usability } \\
\hline Interval & Kategori \\
\hline $20 \%-$ & Sangat tidak layak \\
$35,99 \%$ & \\
\hline $36 \%-$ & Tidak layak \\
$51,99 \%$ & \\
\hline $52 \%-$ & Cukup layak \\
$67,99 \%$ & \\
\hline $68 \%-$ & Layak \\
$83,99 \%$ & \\
\hline $84 \%-100 \%$ & Sangat layak \\
\hline
\end{tabular}

Berdasarkan table diatas [5], maka hasil presentase pengujian dengan nilai 94,66\% masuk dalam kategori "Sangat Layak" dan memenuhi aspek usability.

\section{KESIMPULAN}

Sistem Informasi Penerimaan Mahasiswa Baru berbasis website pada Universitas Karyadarma Kupang dikembangkan menggunakan PHP MySQL dan berdasarkan model pengembangan Waterfall yaitu, (1) studi kelayakan (2) investigasi (3) analisis (4) perancangan (5) penerapan (6) peninjauan dan 
perawatan. Hasil pengujian kualitas perangkat lunak pada aspek usability menghasilkan skor total nilai 2698 yang dikonversikan kedalam skala index mendapatkan nilai sebesar 94,66\%. Kemudian presentase sebesar 94,66\% dikonversikan kedalam skala kualitatif menghasilkan skala penilaian "Sangat Layak". Sehingga dapat disimpulkan sistem informasi manajemen ekstrakurikuler sudah memenuhi aspek usability dinyatakan layak untuk digunakan.

\section{DAFTAR PUSTAKA}

[1] Olsina, L., Godoy, D., \& Lafuente, G. J., Specifying quality characteristics and attributes for websites", 2003.

[2] Samiaji, Sarosa. Metodologi Pengembangan Sistem Informasi. Jakarta barat: Indeks Jakarta. 2017.

[3] Ladjamudin, A.-B. b., 2005. Analisis dan Desain Sistem Infomasi. Yogyakarta: Graha Ilmu.

[4] Sugiyono. Metode Penelitian Pendidikan (Pendekatan Kuantitatif, Kualitatif, dan R\&D). Bandung: Alfabeta. 2016.

[5] Ahi, Sholihin, Saragih.. "Sistem Informasi Perpustakaan Sekolah Berbasis Visual Basic di SMK Muhammadiyah 2". Skripsi. Fakultas Teknik, Pendidikan Teknik Informatika, Universitas Negeri, Yogyakarta, 2017. 